\title{
TWO NEW CATFISH SPECIES OF THE GENUS PSEUDECHENEIS BLYTH (TELEOSTEI: SILURIFORMES) FROM NORTHEASTERN INDIA
}

\author{
W. Vishwanath ${ }^{1}$ and A. Darshan ${ }^{2}$ \\ 1, 2 Department of Life Sciences, Manipur University, Canchipur, Manipur 795003, India \\ Email: ${ }^{1}$ vnath54@yahoo.co.in
}

plus web supplement of 2 pages

\begin{abstract}
Two new catfish species of the genus Pseudecheneis, viz., $P$. ukhrulensis sp. nov. and P. sirenica sp. nov. are described from northeastern India, from streams of Ukhrul district, Manipur (Chindwin basin) and Siren River, Upper Siang District, Arunachal Pradesh (Brahmaputra basin), respectively. The two species can be distinguished from their closest congener P. sulcata in having prominent bony spurs on the anterodorsal surface of the first dorsal-fin pterygiophore (vs. absent), from $P$. crassicauda in shallower caudal peduncle, from $P$. serracula in shorter adipose fin base and from $P$. stenura in deeper caudal peduncle. P sirenica sp. nov. is distinguished from $P$. eddsi in its longer pelvic fin and anal fin and from $P$. ukhrulensis sp. nov. in having longer pectoral fin and caudal peduncle. A key to identification of Pseudocheneis of India and Nepal is given.
\end{abstract}

\section{KEYWORDS}

Aunachal Pradesh, Manipur, new species, Two Pseudecheneis

Abbreviations

MUMF - Manipur University Museum of Fishes, Canchipur;

SL - standard length; TL - total length; HL - head length.

Catfishes of the genus Pseudecheneis Blyth occur in the headwaters of major river drainages throughout South and Southeast Asia. The genus is easily diagnosed from other glyptosternines by a thoracic adhesive apparatus consisting of transverse ridges separated by grooves, respectively called laminae and sulcae (de Pinna, 1996; Roberts, 1998).

While describing two new Pseudocheneis species, viz., $P$. crassicauda and P. serracula from Ganges river drainage, Nepal, $\mathrm{Ng} \&$ Edds (2005) also considered five species of the genus as valid, viz., $P$. sulcata (McClelland) of Brahmaputra drainage; $P$. paviei Vaillant of Red River drainage and P. immaculatus Chu, P. sulcatoides Zhou \& Chu and P. sympelvica Roberts of Mekong drainage. They considered $P$. intermedius Chu, a junior synonym of P. paviei. Zhou \& Chu (1992) considered P. tchangi (Hora), a synonym of P. sulcata. $\mathrm{Ng}$ (2006) described P. stenura from Irrawaddy drainage in southern China and $P$. eddsi from Ganga drainage, Nepal. He redescribed $P$. sulcata and revalidated $P$. tchangi as a distinct species. Thus, 10 species of the genus are presently known.

Several collections of catfishes from different parts of northeastern India have been examined to study the biodiversity of catfishes in this region. The collection includes specimens belonging to the genus Pseudecheneis, of which two were found undescribed. First dorsal fin pterygiophore of eight specimens of P. sulcata collected from Tista River, Sikkim were examined. The structure is described here. A key to identification of known Pseudecheneis from India and Nepal is given.

Material and Methods

The specimens examined were preserved in $10 \%$ formalin and deposited in MUMF. Measurements were taken using dial calipers and data recorded to tenths of a millimeter. Subunits of head are expressed as proportions of head length. Head length and measurements of body parts are given as the proportion of standard length. Counts and measurements follow those of $\mathrm{Ng} \&$ Rainboth (2001). The number in parenthesis after a particular count is the number of specimen with that count. Inter pelvic gap is the distance between the inner bases of pelvic fins. Clearing and staining of bones follow Hollister (1934). Osteological data were taken from both radiographs and alizarin stained specimens. Drawings of osteological structure were traced directly from radiographs and photographs of stained specimens.

\section{PSEUDECHENEIS UKHRULENSIS sp. nov. (Image $1^{\mathrm{w}}$; Fig. 1)}

\section{Materials examined}

Holotype: 2.iii.1998, Momo stream, Tusom C.V., Ukhrul district, Manipur, India, 117.7mm SL, coll. Kosygin (MUMF 2280)

Paratypes: 3:1 ex., 21.xi.1994, Wanze stream, Khamsom, Ukhrul district, Manipur, India, 110.0mm SL, coll. Kosygin (MUMF 2214); 1 ex., 5.v.1997, Chatrickong River at Khyayang, Ukhrul district, Manipur, India, 125.6mm SL, coll. Selim (MUMF 3001); 1 ex., 19.iv.1996, Chatrickong river, Ukhrul district, Manipur, India, 120.3mm SL, coll. WVS (MUMF 9090).

\section{Distribution}

Presently known from streams draining to Tizu River in northern part of Ukhrul district and Chatrickong river in southern part of the district, Manipur, both Chindwin drainage.
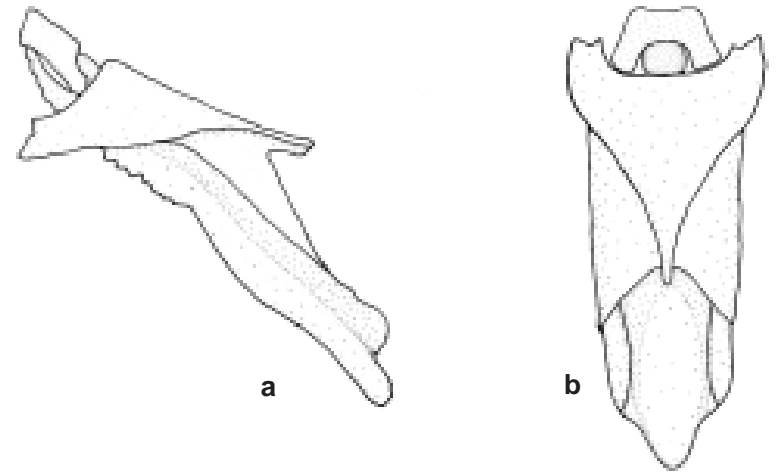

Figure 1. a - Lateral view; b - Dorsal view. First dorsal fin pterygiophores of Pseudecheneis ukhrulensis sp. nov.

w See Image 1 in the websupplement at www.zoosprint.org Manuscript 1608; (C) ZOO; Date of publication 21 February 2007 Received 03 August 2006; Finally accepted 20 January 2007 


\section{Etymology}

Named after Ukhrul district, where it is distributed.

\section{Diagnosis}

Pseudecheneis ukhrulensis sp. nov. is differentiated from its congeners by the following combination of characters: first dorsal-fin pterygiophore with a prominent bony spur on the anterodorsal surface, longest ray of pelvic fin not reaching anal fin origin, inter pelvic gap 2.1-2.6 as wide as eye diameter, rounded caudal peduncle, snout length 66.9-69.0 and eye diameter 10.6-12.1\% HL, pectoral fin length $23.9-24.9 \%$ SL, caudal peduncle length $24.9-26.1 \% \mathrm{SL}$ and its depth $4.3-4.9 \% \mathrm{SL}$.

\section{Description}

Morphometric data are given in Table 1. Dorsal profile rising gently from tip of snout to origin of dorsal fin, and then sloping very gently ventrally to the end of caudal peduncle. Ventral profile roughly horizontal till the origin of anal fin and sloping gradually to the end of caudal fin. Caudal peduncle long and rounded. Skin smooth, but tubercles sparsely appear on head and predorsal region. Lateral line complete and midlateral. Vertebrae $18+18=36(2)$ or $18+19=37$ (2). Gill rakers on the first branchial arch $2+10=12(1)$. Branchiostegal rays 7 (1).

Gill opening moderate, extending from post temporal region to base of first pectoral fin element. Ventral surface of head with unculiferous collar on distal margin of branchiostegal membrane immediately anterior to thoracic adhesive apparatus. Thoracic adhesive apparatus consisting of 14-16 laminae, posterior ridges frequently not meeting at mid line, its length 1.5-1.6 times its width, extending immediately posterior to collar on distal margin of branchiostegal membrane to the level of the tip of innermost last pectoral fin ray. Eyes small, almost rounded, subcutaneous and located on the dorsal surface of head.

Mouth inferior, with thin papillate lips. Rictal lobe large and papillate. Teeth are arranged in irregular rows, outer row of teeth is large and oar shaped inner rows shorter and conical on both jaws. Premaxillary tooth band roughly semicircular not exposed when mouth is closed. Dentary tooth band tapering laterally to the angle of mouth and slightly wider than premaxillary.

Barbels four pairs and flattened. About $70 \%$ length of maxillary barbel attached to snout by large thin flap of skin, ventral surface covered with papillae, its distal tip not reaching to level of anterior orbital rim. Nasal barbel with small flap of skin at its base and its tip not reaching midway between posterior nares and anterior orbital margin. Mandibular barbels densely covered with papillae. Inner mandibular barbel short and its distal tip not reaching collar on distal margin of branchiostegal membrane. Outer mandibular barbel originates posterlateral of inner mandibular barbel and extends to level of anterior orbital rim.

Dorsal fin with i,6 (4) rays. Fin margin straight. Adipose fin margin deeply convex, posterior half of fin margin membranous and shallowly incised at posterior most extremity. Pectoral fin enlarged with convex anterior margin, reaching to middle of pelvic fin base. First element not ossified, broadened and ventral surface with regular striae but smooth at the base and distal portion, fin with i,14 (4) rays. Pelvic fin with i,5 (4) rays. Pelvic origin opposite to the base of last third branch ray of dorsal fin, its longest ray reaches anterior rim of anal opening, inter pelvic gap, 2.1-2.6 of eye diameter. Outer fin margin convex, its first simple ray broadened and ventral surface with prominent regular striae, distal fin margin concave. Anal fin with iv,7 (1) or iii,8 (3) Caudal fin with i,7,8,i (4) principle rays, deeply emarginated, both lobes pointed, lower slightly longer, procurrent rays symmetrical and extends slightly anterior to caudal base.

\section{Colouration}

In 10\% formalin, dorsal and lateral surface of body dark brown and ventral part of body and head very light brown. Body with distinctive series of pale yellowish blotches: one ovate on dorsal origin, one circular on each side of body immediately lateral to the bases of last dorsal fin ray which were faintly interconnected dorsally at the posterior most extremity of dorsal fin base, two blotches on each sides, below adipose origin one above and another below the lateral line; a circular spot on each side at the posterior end of adipose fin which faintly inter connected dorsally and another pair at the caudal fin base. Adipose fin brownish with yellowish margin at the origin and posterior slopes. Anal fin with yellowish band at the middle and distal tip.

\section{Osteology}

First dorsal fin pterygiophore with prominent bony spur (Fig. 3a, b), lateral facet of this pterygiophore attached to the bifit neural spine of fourth vertebra.

Anterior fontanel long, tapering anteriorly, extending from middle of posterior nares to the level of posterior rim of eye. Posterior fontanel tapering posteriorly, commencing form posterior end of epiphysal bar to the middle of supraoccipital. Caudal fin is supported by last four vertebras. Procurrent rays with 9 on the upper and eight (1) on the lower lobe. Parhypural fused with first and second hypural plate on lower lobe and hypural third, forth, fifth and sixth fuse on the upper lobe. Single epural present with pointed proximal end and distal portion wider laterally. Primary and secondary hypuropo-physis fuse.

\section{PSEUdeChENEIS SIRENICA sp. nov. \\ (Image $2^{\mathrm{w}}$; Fig. 2)}

\section{Materials examined}

Holotype: 5.i.2006, Siren river, Upper Siang district, Brahmaputra river drainage, Arunachal Pradesh, India, 109.8mm SL, coll. WVS and party (MUMF 9070/1)

Paratypes: 5 exs. 5.i.2006, Siren River, Upper Siang District, Brahmaputra River drainage, Arunachal Pradesh, India, 87.0102.2mm SL, coll. WVS and party (MUMF 9070/2-3)

\section{Etymology}

Named after Siren river, its type locality.

\section{Diagnostic}

Pseudecheneis sirenica sp. nov. is distinguished from its

w See Image 2 in the websupplement at www.zoosprint.org 
congeners by the following combination of characters: first dorsal-fin pterygiophore with a prominent bony spur on the anterodorsal surface, pelvic ray reach anal fin origin, inter pelvic gap 1.0-1.5 as wide as eye diameter, rounded caudal peduncle, pectoral fin length with 23.9-24.9\% SL, long anal fin, its length $17.5-21.7 \%$ SL; caudal peduncle depth $4.1-4.4 \%$ SL and adipose fin base length 22.7-23.1\% SL.

\section{Description}

Morphometric data are given in Table 1. Dorsal profile rising gently from tip of snout to origin of dorsal fin then runs almost horizontally towards the origin of adipose fin and sloping very gently ventrally to the end of caudal peduncle. Ventral profile roughly horizontal till the origin of anal fin and sloping gradually to the end of caudal fin. Caudal peduncle is long and rounded. Skin smooth, but tubercles sparsely appear on head and predorsal region. Lateral line complete and midlateral. Vertebrae with $18+18=36$ (1) or $18+19=37$ (2) or $19+18=37$ (3). Gill rakers on the first branchial arch with 2 $+10=12$ (1). Branchiostegal rays 7 (1).

Gill opening moderate, extending from post temporal region to base of first pectoral fin element. Ventral surface of head with unculiferous collar on distal margin of branchiostegal membrane immediately anterior to thoracic adhesive apparatus.

Thoracic adhesive apparatus consisting of 14-16 laminae, posterior ridges frequently not meeting mid-line, its length 1.5-1.6 times its width, extending immediately posterior to collar on distal margin of branchiostegal membrane to the level of last pectoral fin ray tip. Eyes small almost rounded, subcutaneous and located on the dorsal surface of head.

Mouth inferior, with thin papillate lips. Rictal lobe large and papillate. Premaxillary tooth band not exposed when mouth is closed. Premaxillary teeth short and conical, arranged in irregular rows on roughly semi-circular patch. Dentary teeth large, tips rounded and arranged in irregular rows. Tooth band tapering laterally to the angle of mouth broadest at the symphysis.

Barbel four pairs, flattened. Maxillary barbel extends to level of anterior orbital rim; proximal portion (about $60 \%$ of its length) is attached to the snout via large thin flap of skin. Nasal barbels with small flap of skin at its base and extend to the midway to distance between posterior nares and anterior orbital margin. Inner mandibular barbel densely covered with papillae; extending to collar on distal margin of branchiostegal membrane. Outer mandibular barbel originates posterlateral of inner mandibular barbel extending to level of anterior orbital rim.

Dorsal fin with i,6 (6) rays. First and second dorsal fin-ray elements not ossified. Fin margin slightly concave. Adipose fin margin gently convex, posterior half of fin margin membranous and posterior most extremity shallowly incised. Pectoral fin enlarged with S shaped posterior margin, reaching to base of last branch ray. First element not ossified, broadened and ventral surface with regular striae but smooth near the base and distal portion, fin with i,14 (6) rays. Pelvic fin rays horizontal to the body, with i,5 (6) rays. Pelvic origin opposite to the base of second or third branch ray of dorsal fin, distal tip of inner rays reach anal opening, outer first branch ray
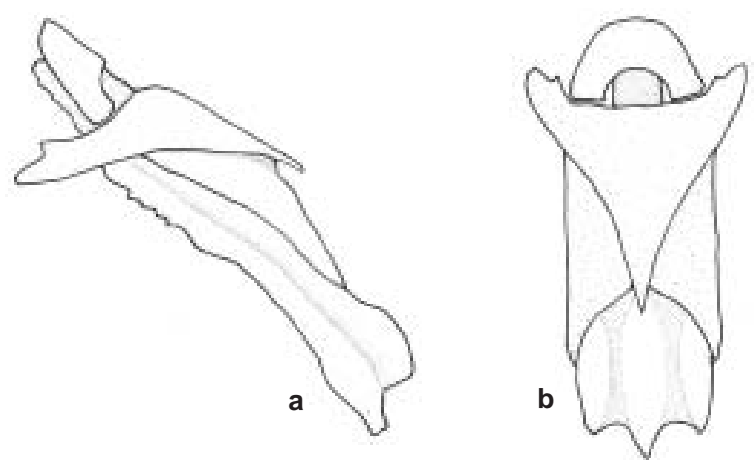

Figure 2. a - Lateral view; b - Dorsal view. First dorsal fin pterygiophores of Pseudecheneis sirenica sp. nov.

extended reaching anal origin, pelvic fin separated by a gap slightly more than its eye diameter. Outer fin margin convex, its first simple ray broadened and entire length of the ventral surface with 40-50 prominent regular striae, distal margin concave. Anal with iii, 8 (6) rays, outer rays longer, posterior fin margin straight, extend beyond the level of posterior extremity of adipose fin. Caudal fin with i,7,8,i (6) principle rays, deeply emarginated, both lobes pointed, lower slightly longer, procurrent rays symmetrical and extends slightly anterior to caudal base.

\section{Colouration}

In $10 \%$ formalin, dorsal and lateral surface of body dark brown and ventral part of body and head very light brown. Body with distinctive series of pale yellowish blotches: one ovate on dorsal origin, one circular on each side of body immediately lateral to the bases of last dorsal fin ray, two roughly circular blotches one above and another below the lateral line, on each side of body at adipose origin; one circular spot each on both side at the posterior end of adipose fin which faintly inter connected dorsally and another pair at the caudal fin base.

Adipose fin dark brown, with yellowish distal margin on the posterior half and origin. Dorsal surface of pectoral and pelvic fin brown with yellowish band on inner half but not reaching outer margin, hyaline distal margin. Dorsal and anal fin with yellowish band in the middle with hyaline distal margin. Caudal fin brown with yellowish band in the middle and distal tips of both lobes yellowish.

\section{Osteology}

First dorsal fin pterygiophore with prominent bony spur (fig. 3c \& d), lateral facet of this pterygiophore attached to the bifit neural spine of fourth vertebra. Anterior fontanel long, tapering anteriorly, extending from middle of posterior nares to the level of posterior rim of eye. Posterior fontanel tapering posteriorly, extending form posterior end of epiphysal bar to the middle of supraoccipital. Caudal fin is supported by last four vertebras. Procurrent rays symmetrical with eight (1) procurrent rays on both lobes. Parhypural fused with first and second hypural plate on lower lobe and hypural third, forth, fifth and sixth fuse on the upper lobe. Single epural present with pointed proximal end and wider distally. Primary and 
secondary hypuropophysis fuse.

\section{First dorsal fin pterygiophore of Pseudocheneis sulcata:}

The anterior portion of first nuchal plate is completely fused to the dorsal surface of first proximal radial leaving only indistinct marking of its presence. This condition refers to the absence of bony spur on the first dorsal fin pterygiophore (Fig. 3).

\section{Disscusion}

Pseudecheneis ukhrulensis sp. nov. is distinguished from $P$. sulcata, $P$. paviei, $P$. sulcatoides and $P$. sympelvica in having a prominent bony spur on the antero-dorsal surface of the first dorsal fin pterygiophore. It also differs from $P$. sulcata in having wider interpelvic gap (2.1-2.6 vs. 1-1.3 as wide as eye diameter), shorter pelvic fin (20.1-21.1 vs. 21.2-28.7\% SL), deeper head (13.4-15.9 vs. 10.1-13.9\% SL) and larger eye (10.6-12.1 vs. $8.8-10.6 \%$ SL). P. ukhrulensis sp. nov. is similar to $P$. stenura in having wider interpelvic gap, but distinguished from the later in its shorter pectoral fin (23.9-24.9 vs. 26.2$31.7 \% \mathrm{SL})$, post adipose distance (18.3-18.9 vs. 20.6-25.4\% SL) and caudal peduncle (24.9-26.1 \% SL vs. 30.3-34.5); deeper caudal peduncle (4.3-4.9\% SL vs. 2.9-3.6) and head (13.4-15.9 \% SL vs. 10.4-12.9). The new species differs from P. eddsi in having deeper body at anus (16.0-17.3 vs. 11.0$14.5 \% \mathrm{SL})$ and head (13.4-15.9 vs. $11.3-14.1 \% \mathrm{SL})$; and more number of pectoral fin branched rays (14 vs. 12-13). It also differs from $P$. sirenica in having shorter pelvic fin (20.1-21.3 vs. $22.1-23.2 \% \mathrm{SL})$, pectoral fin (23.9-24.9 vs. $27.9-29.9 \% \mathrm{SL})$, caudal fin (18.9-19.3 vs.22.4-23.9\% SL) and caudal peduncle (24.9-26.1\% SL vs. 27.6-30.2); deeper body at anus (16.017.9 vs. $14.9-15.4 \% \mathrm{SL}$ ); and longer snout (66.9-69.0 vs. 63.9$65.2 \% \mathrm{HL}$ ). In the new species, the longest ray of pelvic fin does not reach the anal fin origin while in case of $P$. serracula and $P$. crassicauda, the ray reach anal fin origin.

Pseudecheneis sirenica sp. nov. is distinguished from its closest congener P. sulcata in having a prominent bony spur on the anterodorsal surface of the first dorsal-fin pterygiophore (vs. absent), longer adipose fin base (22.7-23.1 vs. 17.8-22.7\% SL), shorter inter-dorsal distance (13.8-14.1 vs. $14.2-21.4 \% \mathrm{SL})$, and anal fin (17.5-21.7 vs. $11.9-14.2 \% \mathrm{SL})$, deeper head (14.014.6 vs. $10.1-13.9 \% \mathrm{SL})$ and more numbers of laminae on thoracic adhesive device (14-16 vs.12-14). It differs from $P$. crassicauda by its deeper body at anus (14.9-15.4 vs. 12.9-14.7\% $\mathrm{SL})$, lower caudal peduncle depth (4.1-4.4 vs. 6.0-6.6\% SL), deeper head (14.0-14.6 vs. 12.0-13.0\% SL), larger eye (8.710.8 vs. $7.5-8.3 \%$ HL) and longer outer mandibular barbel (29.4-31.6 vs. 23.4-28.7).

P. sirenica sp. nov. differs from $P$. serracula in having shorter adipose fin base (22.7-23.1 vs. 26.8-30.4\% SL). It has $36-37$ (18-19+18-19) vertebra, which is similar to $P$ serracula. However, it differs from $P$. serracula in having 2-3 preanal and first 6-7 postanal neural spines have gradual increasing in height (vs. strongly elevated). It is distinguished from $P$. stenura in its deeper caudal peduncle (4.1-4.4 vs. $2.9-3.6 \% \mathrm{SL})$, head (14.0-14.6 vs. 10.4-12.9\% SL), and body at anus (14.915.4 vs. $11.3-14.2 \% \mathrm{SL}$ ), shorter caudal peduncle (27.6-30.2 vs. $30.3-34.5 \% \mathrm{SL})$. It is also differentiated from $P$. eddsi in its

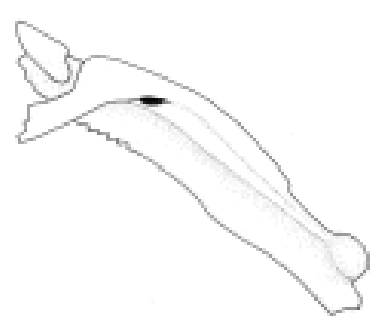

Figure 3. First dorsal fin pterygiophores of Pseudecheneis sulcata (lateral view)

longer pelvic fin (22.1-23.2\% SL vs. 18.0-20.9) and anal fin (17.5-21.7\% SL vs. 10.9-13.3).

$P$. sirenica sp. nov. and $P$. ukhrulensis sp. nov. differ from $P$. immaculata in having pale spots on the body (vs. absence) and shorter adipose fin base (21.1-23.5 vs. 27.7\% SL); from $P$. sympelvica in having separate pelvic fins (vs. fused) and from $P$. sulcatoides in the presence of 'spinelet', first dorsal fin element (vs. absence) and from $P$. paviei in having more laminae of adhesive apparatus (14-16 vs. 10-11).

P. sulcata (Mclelland, 1842) was originally described from Brahmaputra basin in Khasi hills, Meghalaya. Ng (2006) redescribed $P$. sulcata and reported of its restricted distribution in the Brahmaputra river drainage. He reported of the absence of bony spur on the first dorsal fin pterygiophores of P. sulcata, $P$. paviei, $P$. sulcatoides and $P$. sympelvica.

Distance between inner bases of pelvic fin has been an important character in the identification of Pseudecheneis species. Hora (1937) also reported of the species specificity of form and position of fins in the genus.

Reports of occurrence of $P$. sulcata in the headwaters of Chindwin drainage in Manipur by Arunkumar \& Singh (1997); Selim \& Vishwanath (1997), and Vishwanath et al. (1998) need further examination as Pseudecheneis species are known to have very restricted distribution ( $\mathrm{Ng} \&$ Edds, 2005).

\section{Comparative MATERIALS}

1. Pseudecheneis sulcata: MUMF 9090 (8), 70.4-103.6 mm SL; India: Sikkim, Tista River; and morphometric data of $\mathrm{Ng}$ (2006).

\section{REFERENCES}

Arunkumar, L. \& H.T. Singh (1997). On a collection of fishes from the head water of Yu-River System with four new records in Manipur. Journal of Freshwater Biology 9(3-4): 126-133.

Hollister, G. (1934). Clearing and dyeing fishes for bone study. Zoologica 12:89101 .

de Pinna, M.C.C. (1996). A phylogenetic analysis of the Asian catfish families Sisoridae, Akysidae, and Amblyciptidae, with a hypothesis on the relationships of the neotropical Aspredinidae (Teleostei: Ostariophysi). Fieldiana: Zoology (New Series) 84: 1-83.

Hora, S.L. (1937). Notes on fishes in the Indian Museum, 36. On a new genus of Chinese catfishes allied to Pseudocheneis Blyth. Records of Indian Museum 39: 348350 .

Keishing, S. \& W. Vishwanath (1999). On a collection of fishes from the southern part of Ukhrul District, Manipur. Journal of the Bombay Natural History Society 96(1): 64-69.

Mclelland, J. (1842). On the fresh-water fishes collected by William Griffith, Esp., F.L.S. Madras Medical Service, during his travel under the orders of the Supreme Government of India, from 1835 to 1842. Calcutta Journal of Natural History 2: 560-589. 
Table 1. Morphometric data of Pseudecheneis ukhrulensis sp. nov. and Pseudecheneis sirenica sp. nov.

\begin{tabular}{|c|c|c|c|c|}
\hline & \multicolumn{2}{|c|}{ Pseudecheneis ukhrulensis sp. nov. } & \multicolumn{2}{|c|}{ Pseudecheneis sirenica sp. nov. } \\
\hline & Holotype & $\begin{array}{l}\text { Holotype \& paratypes } \\
\text { Mean (Range) } \pm \text { SD }\end{array}$ & Holotype & $\begin{array}{l}\text { Holotype \& paratypes } \\
\text { Mean (Range) } \pm \text { SD }\end{array}$ \\
\hline \multicolumn{5}{|l|}{ Percentages SL } \\
\hline Predorsal length & 33.4 & $34.8(33.4-36.0) \pm 1.3$ & 32.1 & $32.0(31.9-32.2) \pm 0.2$ \\
\hline Pre anal length & 60.6 & $60.8(60.0-61.8) \pm 0.8$ & 59.5 & $60.6(59.5-61.3) \pm 1.0$ \\
\hline Pre pelvic length & 38.6 & $37.7(36.7-38.8) \pm 1.2$ & 36.5 & $38.4(36.5-41.9) \pm 3.1$ \\
\hline Pre pectoral length & 18.6 & $18.5(18.3-18.9) \pm 0.3$ & 16.8 & $16.9(16.8-17.2) \pm 0.3$ \\
\hline Length of dorsal fin base & 12.3 & $12.5(12.2-12.9) \pm 0.4$ & 12.1 & $12.0(11.7-12.3) \pm 0.4$ \\
\hline Anal fin length & 19.2 & $20.0(19.2-21.1) \pm 1.2$ & 21.7 & $19.1(17.5-21.7) \pm 2.3$ \\
\hline Pelvic fin length & 20.1 & $20.4(20.1-21.3) \pm 0.6$ & 23.2 & $22.6(22.1-23.2) \pm 0.6$ \\
\hline Pectoral fin length & 24.2 & $24.4(23.9-24.9) \pm 0.5$ & 27.9 & $28.7(27.9-29.9) \pm 1.1$ \\
\hline Caudal fin length & 18.9 & $18.9(18.1-19.5) \pm 0.7$ & 22.4 & $23.1(22.4-23.9) \pm 0.8$ \\
\hline Length of adipose fin base & 23.2 & $22.2(21.1-23.5) \pm 1.3$ & 22.7 & $22.8(22.7-23.1) \pm 0.2$ \\
\hline Dorsal to adipose distance & 12.9 & $14.6(12.8-16.7) \pm 2.2$ & 14.1 & $13.9(13.8-14.1) \pm 0.2$ \\
\hline Post-adipose distance & 18.3 & $18.5(18.3-18.9) \pm 0.3$ & 22.0 & $20.6(19.8-22.0) \pm 1.2$ \\
\hline Caudal peduncle length & 24.9 & $25.3(24.9-26.1) \pm 0.8$ & 29.9 & $24.9(27.6-30.2) \pm 4.9$ \\
\hline Caudal peduncle depth & 4.6 & $4.6(4.3-4.9) \pm 0.3$ & 4.2 & $4.2(4.1-4.4) \pm 0.2$ \\
\hline Body depth at anus & 16.0 & $16.7(16.0-17.3) \pm 0.6$ & 15.2 & $15.1(14.9-15.4) \pm 0.3$ \\
\hline Head length & 18.9 & $18.8(18.3-19.1) \pm 0.3$ & 18.3 & $18.4(18.2-18.8) \pm 0.3$ \\
\hline Head width & 16.8 & $17.4(16.8-18.0) \pm 0.7$ & 16.2 & $16.8(16.2-17.3) \pm 0.6$ \\
\hline Head depth & 13.4 & $15.2(13.4-15.9) \pm 1.3$ & 14.2 & $14.8(14.0-14.6) \pm 0.3$ \\
\hline \multicolumn{5}{|l|}{ Percentages HL } \\
\hline Snout length & 66.9 & $68.1(66.9-69.0) \pm 1.0$ & 65.2 & $64.6(63.9-65.2) \pm 0.7$ \\
\hline Interorbital distance & 28.3 & $28.9(28.3-29.5) \pm 0.6$ & 29.9 & $30.0(29.3-31.0) \pm 0.9$ \\
\hline Eye diameter & 10.6 & $11.1(10.6-12.1) \pm 0.7$ & 8.9 & $9.4(8.7-10.8) \pm 1.2$ \\
\hline Nasal barbel length & 17.8 & $18.1(17.8-18.2) \pm 0.4$ & 22.3 & $22.8(21.7-24.5) \pm 1.5$ \\
\hline Maxillary barbel length & 50.9 & $47.9(45.1-50.9) \pm 3.1$ & 58.2 & $56.6(53.1-60.4) \pm 3.3$ \\
\hline Inner mandibular barbel length & 18.7 & $17.2(16.1-18.7) \pm 1.2$ & 22.4 & $21.3(18.9-22.8) \pm 2.2$ \\
\hline Outer mandibular barbel length & 27.8 & $25.1(22.1-27.9) \pm 3.2$ & 29.4 & $30.5(29.4-31.6) \pm 1.2$ \\
\hline
\end{tabular}

Key to the species of Pseudecheneis of India and Nepal

1. Bony spur in the first dorsal fin pterygiophore absent (Brahmaputra river drainage) ........................... P. sulcata

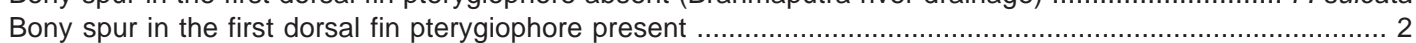

2. Longest ray of pelvic fin reaching anal origin or beyond …........................................................... 3

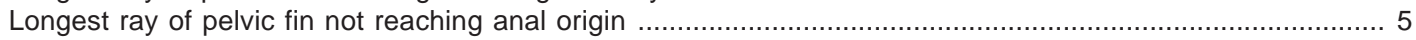

3. Caudal peduncle depth 6.0-6.6\% SL, eye diameter 7.5-8.3\% HL (Ganga river drainage, Nepal) ......... P. crassicauda Caudal peduncle depth below 6.0-6.6\% SL, eye diameter above $7.5-8.3 \% \mathrm{HL}$............................................. 4

4. $\quad$ Adipose fin base long, its length 26.8-30.4\% SL; post adipose short (12.9-17.0\% SL); neural spines of last 23 preanal and first 6-7 postanal vertebra strongly elevated (Ganga river drainage, Nepal) .................. P. serracula Adipose fin base short, its length 22.7-23.1\% SL, post adipose long (19.8-22.0\% SL); neural spines of last 23 preanal and first 6-7 postanal vertebra gradually increase in height (Brahmaputra river drainage, Arunachal Pradesh)

$P$. sirenica sp. nov.

5. Snout long, its length $66.9-69.0 \% \mathrm{HL}$, body deep, its depth $16.0-17.3 \% \mathrm{SL}$, pectoral fin branched ray 14 (Chindwin river drainage, Manipur) ..................................................................... ukhrulensis sp. nov. Snout short, its length 57.7-63.1\% HL; body shallow, its depth 11.0-14.5\% SL, pectoral fin branched ray 12-13 pectoral fin branch ray (Ganga river drainage, Nepal) ..... P. eddsi

Ng, H.H. (2006). The identity of Psudecheneis sulcata (M'Clelland, 1842), with descriptions of two new species of rheophilic catfish (Teleostei: Sisoridae) from Nepal and China. Zootaxa 1254: 45-68.

Ng, H.H. \& D.R. Edds (2005). Two new species of Pseudecheneis, rheophilic catfishes (Teleostei: Sisoridae) from Nepal. Zootaxa 1047: 1-19.

Ng, H.H. \& W.J. Rainboth (2001). A review of the sisorid catfish genus Oreoglanis (Siluriformes: Sisoridae) with descriptions of four new species. Occasional Papers of the Museum of Zoology the University of Michigan 732: 1-34.

Roberts, T.R. (1998). Pseudocheneis sympelvicus, a new species of rheophilic Sisorid catfish from Laos (Mekong basin). The Raffles Bulletin of Zoology 46: 289-292.

Selim, K. \& W. Vishwanath (1997). Ichthyological inves-tigation in Chatrickong River of Ukhrul District, Manipur. Journal of Freshwater Biology 9(3-4): 134137.

Vishwanath, W., W. Manojkumar, L. Kosygin \& S. Selim (1998). Biodiversity of freshwater fishes of Manipur, India. Italian Journal of Zoology, Supplement 65:
$321-324$.

Zhou, W. \& X.L. Chu (1992). A new species of Pseudecheneis with comment on Osteological differentiations at species level (Siluriformes: Sisoridae). Acta Zootaxonomica Sinica 17: 110-115. (in Chinese with English summary)

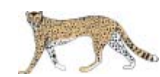

